\title{
Linking transformational leadership with organizational health of secondary school teachers: A conceptual model and research proposition
}

\author{
Anantha Raj A. Arokiasamy
}

Xiamen University Malaysia,

Persiaran Sunsuria, Bandar Sunsuria, 43900 Sepang, Selangor, Malaysia

Dr, School of Economics and Management

\section{open $(2$ access (cc) dol}

Article history:

Received: January 10, 2018

1st Revision: February 10,

2018

Accepted: March 12, 2018

JEL classification:

A21

H75

I21

DOI:

10.14254/jems.2018.3-1.2

\begin{abstract}
This study aims to determine the level of transformational leadership practices by school principals in the national secondary schools in the Northern States of Peninsular Malaysia. The study also aims to determine if school culture acts as a moderator to the relationship between transformational leadership and organizational health of the secondary school teachers' in the 3 states in Malaysia. Despite transformational leadership being commonly practiced, there is a dearth of research, conceptual and empirical, focusing on school culture as moderator to the relationship. To attempt to fill this void, this article develops a conceptual model on school culture functioning as a moderator to the relationship between transformational leadership and organizational health of secondary school teachers and provides explanation of their effects through a statistical methodology. Finally, the author discusses the managerial implications of their research and offer suggestions for future empirical research.
\end{abstract}

Keywords: transformational leadership style, school culture, organizational health, job satisfaction, school principals.

\section{Introduction}

There is great interest in educational leadership in the early part of the $21^{\text {st }}$ century. This is because of the widespread belief that the quality of leadership makes a significant difference to school and student outcomes. In many parts of the world, including both developed and developing countries, there is recognition that schools require effective leaders and managers if they are to provide the best possible education for their students and learners. As the global economy gathers pace, more governments are realizing that their main assets are their people and that remaining or becoming, competitive depends increasingly on the development of a highly skilled workforce. This 
requires trained and committed teachers but they, in turn; need the leadership of highly effective principals with the support of other senior and middle managers (Zaidatol Akmaliah, 1990).

Transformational Leadership moves individuals toward a level of commitment to achieve school goals by identifying and articulating a school vision, fostering the acceptance of group goals, providing individualized support, providing intellectual stimulation, providing an appropriate model and having high performance expectations (Leithwood \& Jantzi, 2006). For this study, transformational leadership will mean the manner in which the school principal guide and encourage fellow staff to work, communicate the schools' goal and empower them to achieve the schools' vision. The main purpose of this research is to investigate the influence and best practice of transformational leadership, school culture and organizational health of secondary schools in Malaysia as perceived by teachers. By identifying the role played by principals in exercising their duties, this study will attempt to reason out approaches used by principals in motivating their subordinates.

Ensuring success in the modern day environment depends much on the ability of the principal in portraying his or her leadership skills by inspiring others to undertake responsibility and work towards a shared vision of improved education (Spunt, 1999). Practicing good governance techniques like transformational leadership comprising of recognizing, inspiring and supporting others in an organization will lead to embracing positions of leadership (Spector, 1997). Although researchers argue on the uniqueness of their terminology, the myriad of leadership styles be it teacher leadership, transformational leadership, distributed leadership or transactional leadership, they are however intertwined to each other and possibly be closely linked to democratic leadership.

Literature review regarding effective schools in Malaysia concluded with the school's environment playing an important role in students' learning. Schools with good turnover of students are more effective than others in their level of academic achievements (Silins \& Mulford, 2002). It has been observed that the school principal plays a key role in how effective the school is (Seltzer \& Bass, 1990). In an effective school the "principal" acts as a transformational leader and effectively and persistently communicates the school's mission to the staff, parents and students. The principal understands and applies effective leadership skills to enable both students and staff to achieve the desired school and student achievements. Studies on effective school have linked leadership to be the key factor both at primary and secondary schools (Selamat, Nordin \& Adnan, 2013). Reviews by (Selamat, Nordin \& Adnan, 2013) concluded that leadership is necessary to initiate and maintain school improvement. Leadership is not simply about the quality of individual leader although this is, of course, important. It is also about the role that leaders play, their style of management, their relationship to the vision, values and goals of the school and their approach to change.

Organizational health of a school refers to the interpersonal relations of students, teachers and administrators in a school (Hoy et. al., 2013) and was used to examine the climate of schools. Organizational health term has been used in the management literature, mainly as an abstract idea of what constitutes a "good organization structure" (Hersey \& Blanchard, 1996). Heller et al. (1993) asserted that a healthy environment was not only an organization surviving its environment but also a structure constantly using its abilities to cope with difficulties and surviving in the long run. Hoy and Miskel (2013) refined the concept of organizational health as the ability of the organization to successfully adapt to its environment, create solidarity among its members and reach its objectives. This is a real motivation for developing a conceptual framework to make it possible to test the direct and indirect relationship of factors that influence organizational health of secondary school teachers.

\section{Problem Statement}

A review of the literature revealed that studies concerning leadership style and school culture especially in Malaysia are limited. (Zaidatol Akmaliah, 1990) did a study to identify the leadership styles of secondary religious school's principals in the state of Selangor. The study showed that the principals had different leadership styles: directive, supportive, participative and goal-oriented leadership. He concentrated only on secondary religious schools. Another study was done by Ministry of Education (2014) to describe primary school teachers' perceptions of school culture and found that most teachers regard their school culture as positive. An earlier study was conducted in Kuala Lumpur by Ministry of Education (2014) but she focused on three aspects: leadership style, school climate and student achievement. Moreover, her study was conducted in elementary schools.

According to (Nguni, Sleegers \& Denessen, 2006), the success of the school's organization and leadership style is correlated. Transformational leadership of school principals affects student 
achievement and teacher willingness to drive for quality education (Gersten et al., 2001). Cemaloglu et al., (2012) argued that the leadership style of school principals has a significant impact on teachers' job satisfaction and effectiveness of the school. Changes to the leadership style of school principals should not only focus on the technical aspects of the school's administration but emphasize on professional leadership and guidance rendered to the teachers and students at the school. Hence, principals are solely responsible for the professional improvement of teachers to a higher level and to ensure students excel academically (Littrel et al., 1994). Are the secondary school principals in Malaysia practicing transformational leadership in their management of school affairs? Also not much is known about the impact of transformational leadership style on the current situation at secondary schools in Malaysia. Creating conducive environment at schools for students to excel and teachers to perform professionally has placed more emphasis on the role of a principal. It is difficult to evaluate the attributes of principals at secondary schools who are committed to the mission and vision of cultivating a positive school environment.

The study will search for evidence to assess the extent to which transformational leadership and a positive school culture is being practiced at secondary schools in Malaysia. As far as the Malaysian education context is concerned, studies on transformational leadership, school culture and organizational health have not been extensively done. These studies have managed to highlight the significant relationship between the two concepts and at the same time, complement existing knowledge in educational leadership and student achievement. Hopefully the results of this study will be useful in helping principals in Malaysia, to work more effectively with teachers and administrators.

\section{Development of the Research Model}

\subsection{Transformational Leadership}

Transformational leadership is a term that was coined by Muijs et al., (2004) (cited by (Hoy et al., 2013). It is one of the more popular approaches to leadership and has been focused on by many researchers since the early 1980s (Muijs et al., 2004). According to (Hallinger, 2007), transformational leadership is part of the "New Leadership" paradigm, which gives more attention to the charismatic elements of leadership. A transformational leader is defined as one who is able to stimulate, inspire and transform his or her subordinates to strive harder in order to achieve extraordinary outcomes (Geijsel et al., 2003). Griffith (2004) states that this type of leadership inspires followers to believe in their own potential, so as to create a better future for the organization while believing in the leader personally.

Kenneth Leithwood is recognized as a leader in adapting the principles of transformational leadership to the field of education. In 1992, Leithwood and his colleagues undertook a series of studies aimed at determining the meaning and utility of transformational leadership in schools. Their work uncovered three common goals of school principals who exhibited transformational leadership behavior:

I. To help staff members develop and maintain a collaborative school culture

II. To foster teacher development and

III. To help them be more effective problem-solvers

He argued that transformational leadership was relevant for educational leaders because leadership is primarily manifested during times of change, with the nature of change determining the type of leadership needed and held that the need for reform, change and restructuring would continue for the foreseeable future (Leithwood et al., 2004). Seven dimensions of transformational leadership in schools were identified by Leithwood et al., (2004):

1. Building school vision

2. Establishing school goals

3. Providing intellectual stimulations

4. $\quad$ Offering individualized support

5. $\quad$ Modeling best practices and important organizational values

6. Demonstrating high performance expectations

7. Creating a productive school culture and developing structures to foster participation in school decisions

In 1996, Leithwood refined the list to six factors and incorporated these into a survey instrument, the Principal Leadership Questionnaire (PLQ), which consisted of 24 items measuring specific principal behaviors: 
1. Vision Identification: this factor relates to principal behaviors that are aimed at identifying new opportunities for staff members and developing, articulating and inspiring others with his or her vision for the future (Leithwood \& Jantzi, 2006).

2. Modeling: this factor relates to principal behaviors that set an example for the school staff members to follow. These behaviors are consistent with the values that are espoused by the principal (Leithwood \& Jantzi, 2006).

3. Goal Acceptance: this factor encompasses behaviors that promote cooperation among school staff members and assist them to work in unison toward shared goals (Leithwood \& Jantzi, 2006).

4. Individualized Support: transformational leaders display respect and concern for the feelings, needs and problems and an understanding of the skills and interests of organizational members (Leithwood \& Jantzi, 2006).

5. Intellectual Stimulation: principal behaviors that challenge staff members to reexamine some of their assumptions about their work and to reconceive ways to do it are representative of this factor (Leithwood \& Jantzi, 2006).

6. High Performance Expectations: this factor involves behaviors that demonstrate the principal's expectations for excellence, quality and high performance on the part of the staff (Leithwood \& Jantzi, 2006).

\subsection{School Culture}

School culture is a large part of the symbolic approach to organizations. Spunt (1999) show that the symbolic frame centers on the concepts of symbols, myths, rituals and ceremonies. Many of these concepts are included in their framework for understanding culture. When an organization faces an unfamiliar risk, issue, or problem, it bases its first response on the leader's values because the group as a whole has limited or no knowledge of how to resolve the problem (Harris et al., 2013). Vision and values are the foundation of school culture; core values, implicit or explicit, reside at the heart of every institution or organization. Bogler (2001) proposed that schools act based upon how they have defined their purpose. Littrel et al. (1994) saw the principal as the determining factor for "what set of values will be the guiding stars for the school as it steers a new course" (p. 13). School administrators play a big part in what beliefs, values, and assumptions are the most important in the existing school culture, as they can determine what is communicated to whom, who receives resource allocations, and who is in receipt of rewards and disciplinary action (Rahman Sukor, 2010).

School culture is also experienced through rituals and ceremonies. "Principals can shape culture by participating in and encouraging the rituals that celebrate important values" (Leithwood et al., 2004). Ceremonies are an extension of the rituals. They are a complex, culturally sanctioned way to celebrate success, communicate values, or to recognize social contributions of staff and/or students. These celebrations provide an effective means of cultivating a goal-oriented culture where improvement efforts are reinforced and recognized (Hallinger, 2003). Ceremonies give a purpose to meaning, and provide the school community a chance to reflect on the beliefs and values associated with those ceremonies (Spector, 1997). By understanding leadership directly affects culture and culture indirectly influences effectiveness, ineffectiveness within schools can be addressed. When schools do not focus on creating a strong sense of community through culture, employees often feel disengaged and inclined to seek alternative employment opportunities. As mentioned previously, schools with strong culture increase employee morale, thus schools lacking relationships and morale often have high turnover rates (Geijsel et al., 2003). For example, leading to even higher rates of turnover might be turnover itself. Turnover can be attributed to a lack of personal relationships and bonds, which are often characteristic of strong culture and motivation.

The School Culture Survey (Gruenert, 1998) was developed to measure characteristics of school culture after a comprehensive review of 27 articles, chapters and books on school culture. After it was administered to 632 teachers, factor analysis was used to uncover six dimensions of school culture:

1. Collaborative Leadership: describes the degree to which school leaders establish and maintain collaborative relationships with school staff. The leaders' value teacher's ideas, seek their input, engage them in decision-making and trust their professional judgments. Leaders support and reward risk-taking, innovation and sharing of ideas and practices (Gruenert, 1998).

2. Teacher Collaboration: describes the degree to which teachers engage in constructive dialogue that furthers the educational vision of the school. Teachers across the school plan together, observe and discuss teaching practices, evaluate programs and develop an awareness of the practices and programs of other teachers (Gruenert, 1998). 
3. Professional Development: describes the degree to which teacher's value continuous personal development and school-wide improvement. Teachers seek ideas from seminars, colleagues, organizations and other professional sources to maintain current knowledge, particularly current knowledge about instructional practices (Gruenert, 1998).

4. Unity of Purpose: describes the degree to which teachers work toward a common mission for the school. Teachers understand, support and perform in accordance with that mission (Gruenert, 1998).

5. Collegial Support: describes the degree to which teachers work together effectively. Teachers trust each other, value each other's ideas and assist each other as they work to accomplish the tasks of the school organization (Gruenert, 1998).

6. Learning Partnership: describes the degree to which teachers, parents and students work together for the common good of the student. Parents and teachers share common expectations and communicate frequently about student performance. Parents trust teachers. Students generally accept responsibility for their schooling (Gruenert, 1998).

\subsection{Organizational Health}

Generally, there is various definition of organizational health. According to (McLeskey et al., 2004), organizational health can be defined as an approach in which organizational members observe and characterize their surrounding and environment in an attitudinal and value-based manner. In another perspective, (Ministry of Education, 2014) referred organizational health as a 'set of attributes specific to a particular organization that may be induced from the organization, deals with its members and its environment'. Even though little is known about organizational health in the past, however, in the 21st century, organizational health has received a considerable attention by many sectors. According to A. Arokiasamy et al. (2015) organizational health is a psychological state that characterizes the employee's relationships with the organization and has implications for the decision to continue membership in the organization. According to (Hershey \& Blanchard, 1996), there were some factors such as organizational culture, leadership style and human resources practices, which could be deliberately manipulated by organizations to influence the levels of organizational health in their employees. She further suggested that organizational health was a key to increasing public service motivation and recommends more empirical studies of employee commitment. Such studies were warranted for helping to understand the motivational base of public sector employees.

Several researchers have defined the term organizational health as the ability of the organization to successfully adapt to its environment, create harmony among its members, and achieve its goals (Leithwood et al., 2004). Heller et al. (1993) also defined a healthy organization as one that not only survives in its environment, but continues to grow and prosper over time. In addition, healthy organizations avoid persistent ineffectiveness. Heller et al. (1993) conceptualized a healthy organization as one consisting of ten important properties categorized under three main components: (a) task needs including a goal focus, communication adequacy, and power equalization; (b) maintenance needs including resource utilization, cohesiveness, and morale; (c) growth and development needs including innovativeness, autonomy, adaptation, and effective problem-solving. In essence, organizational health of a school is one characterized by (a) interpersonal relationships among people in schools, (b) successfully adjusting to the environment of the school, and (c) promoting common values throughout the school. In addition, researchers have reported that harmonious efforts between technical (i.e., teacher affiliation, academic emphasis), managerial (i.e., collegial leadership and resource information), and institutional levels (i.e., institutional integrity) are needed for a school to be healthy Heller et al. (1993).

In 1987, Hallinger (2007) developed and piloted the Organizational Health Inventory for Secondary Schools (OHI-S). It contained 95 potential items and sampled 72 urbans, suburban, and rural New Jersey schools. The instrument was then refined to 44 items reflecting seven dimensions of school health. These seven dimensions included institutional integrity, principal influence, consideration, initiating structure, resource support, morale, and academic emphasis.

Hoy and his associates defined institutional integrity as the school's ability to cope with its environment and maintain the integrity of its programs. Principal influence was the principal's ability to influence superiors. The principal's friendly, supportive, and collegial behavior defined consideration. Adequate classroom materials and supplies composed the resource support dimension. Morale was the collective sense of friendliness, openness, enthusiasm, and trust among faculty members. And academic emphasis asserted that there was a true quest for excellence in the academic programs of the school (Hoy et al., 2013).

1. Institutional Integrity (II): Hoy \& Miskel, (2013) depicted II as a board-level dimension. In a healthy school-a school with a high II, the board is successful in safeguarding the school 
policies from outside influence, thereby conserving energy for the school's mission. In unhealthy schools - those schools with a low II, parents and other community members have a diminishing influence on the policies made within the school. II represented a major predictor of the faculty members' trust in the school principal. Hoy also discovered teachers to be more committed to schools with a high II.

2. Initiating Structure (IS): Hoy \& Miskel, (2013) considered IS an administration-level dimension of health. A principal who was very clear in articulating work procedures, expectations, and performance standards had a strong IS (Hoy \& Miskel, 2013) one that also correlated positively with teacher commitment to the school (Muijs et al., 2004). On the other hand, Hoy and his colleagues described an unhealthy school as one with no guidance and direction from the principal. Research conducted by [10] found teachers strongly attributed student achievement to the structure of the organization and attributed the success of the structure to leadership practices.

3. Consideration (C): Consideration, another administration-level dimension of health Hoy \& Miskel, (2013), was deemed as high when principal behavior was proved collegial and supportive Hoy \& Miskel, (2013). In other words, the principal's friendliness in a healthy school did not preclude high standards. Hoy found $C$ to be a predictor of trust for faculty members - trust in their principal and in their colleagues, as well. Consideration has been linked to ethical leadership. Gruenert (1998) found a positive correlation between ethical leadership and $\mathrm{C}$. When leaders demonstrated high levels of $\mathrm{C}$, followers performed higher quality work, appeared more satisfied, and perceived the leader as more effective (Spunt, 1999). Leaders with high C scores were found by (Seltzer \& Bass, 1990) experienced fewer turnovers, obtained higher job satisfaction from workers, and received a lower number of grievances filed. However, that same study did show performance levels of the workers to be lower as well. According to Hoy \& Miskel, (2013), principals exemplifying C were found to have stronger systems of management.

4. Principal Influence (PI): Hoy \& Miskel, (2013) considered PI an administrative-level dimension of organizational health. Hoy \& Miskel, (2013) defined PI as the principal's ability to sway the school board and director. PI accompanied by Morale could together predict collegial mutual trust. In Littrel et al.'s (1994) study, influence of the principal was significantly different among high- and low performing middle schools. High performing middle schools scored a lower PI rating than did low performing middle schools.

5. Resource Support (RS): Resource Support is an administrative-level organizational health dimension (Hoy \& Miskel, 2013). The description of RS was given by Hoy \& Miskel, (2013) as a school providing instructional and classroom supplies sufficiently and upon request and making extra resources available when needed. Teacher commitment was partially attributed to RS. A positive correlation between student achievement and RS was found by many researchers (Hoy \& Miskel, 2013).

6. Morale (M): A teacher-level dimension of school health (Heller et al., 1993), M deals with faculty members' rapport, i.e., teachers working together and sharing trust, enthusiasm, and confidence with one another (Hoy \& Miskel, 2013). Gruenert (1998) conducted a study with results indicating a relationship between $M$ and teachers' perceptions of school climate. Specifically, when combined with PI, M was a predictor of faculty members' trust in one another. In a study conducted by (Seltzer \& Bass, 1990), the organizational culture in a middle school was strengthened by trust. Increased accountability has contributed to a decline in teacher and administrator M (Silins \& Mulford, 2002). Morale alone significantly impacted general teacher efficacy, and when combined with AE, it also influenced personal teacher efficacy (Hoy \& Miskel, 2013).

7. Academic Emphasis (AE): Academic Emphasis was another teacher-level dimension of school health as interpreted by Hoy \& Miskel, (2013). Hallinger (2007) described AE as existing in a school focusing on the success of students by setting goals and high expectations and fostering shared respect in pursuit of excellence in academics. They also found AE to be related to faculty members' trust in colleagues. Leithwood et al. (1999) discovered high performing schools had higher mean scores on AE. Uniquely, AE significantly impacted and even predicted the personal efficacy of teachers in the study completed by Geijsel et al. (2003) found strong, positive correlations between AE and student achievement in math, reading, and writing.

\section{The Conceptual Framework}

The conceptual framework for this study was developed from an in depth review of literature examining the theoretical basis of transformational leadership theory as well as its 
evolvement into the public education sector. Transformational leadership theory draws its strength in placing a greater value on the perceived needs of the follower, not the leader; thereby differing greatly from previous leadership theories. Furthermore, it places a high moral standing on the leader, and expects him or her to encourage followers to think for them and for all to work collaboratively. Through this innovative and collaborative process, followers theoretically develop a greater sense of self-efficacy; experience greater job satisfaction and have increased levels of organizational commitment. The confluence of transformational leadership behaviors and school culture on organizational health holds promise of developing a more satisfied and committed teaching staff. Research on the direct and indirect influence of these constructs will provide invaluable information to school principals and those aspiring to become school leaders. Understanding leadership behaviors that are conducive to increasing teacher efficacy, job satisfaction and organizational commitment will provide opportunities for school principals to aid in strengthening organizational health with a more stable, qualified and committed teaching work force.

Based on the review of the literature, there is evidence that clearly indicates that transformational leadership and school culture are correlated. Attempting to understand one without having an understanding of the other will not obtain the desired results. As a result, principals must have a thorough understanding of their role in shaping the school culture, as well as the leadership style that is most appropriate for assisting them in doing so, in order for them to be effective. Increasing the body of knowledge of understanding transformational leadership style would be considered as the best fit for a school's culture could potentially lead to assisting organizations in selecting the best leaders to enhance the effectiveness of the organization. The extensive review of the literature also reveals that one can realize that the mission and goals can affect the leadership style practiced by school principals. This, in turn, transforms into culture and then influences the teachers' effectiveness and student achievement. Therefore, how to increase school improvement of secondary schools through transformational leadership and organizational health is an area that needs to be explored; in particular, the moderating effect of school culture on the relationship between transformational leadership and organizational health. Silins \& Mulford, (2002) noted the possibility of the moderating effects of school culture that might affect school improvement. However, it is surprising that little empirical evidence exists regarding the moderating effect of school culture on teacher effectiveness and student achievement. Although the moderating effect of school culture seems promising, but all these researchers did not test this conceptualization empirically.

In the framework for the current study, transformational leadership is the independent variable, influencing the dependent variable which is organizational health and school culture is the moderating variable. A diagram of this conceptual framework is illustrated in Figure 1.0 below.

\section{Research Hypotheses}

Based on the research objectives and research questions, the research hypothesis was formed to test the validity. Research findings were tested at the level of $p<0.05$. The following are the research hypotheses:

HA1: $\quad$ There is a significant influence of transformational leadership on school culture of secondary schools in the Northern State of Peninsular Malaysia as perceived by teachers.

HA2: $\quad$ There is a significant influence of transformational leadership on organizational health of secondary schools in the Northern State of Peninsular Malaysia as perceived by teachers.

HA3: $\quad$ There is a significant influence of school culture on organizational health of secondary schools in the Northern State of Peninsular Malaysia as perceived by teachers.

HA4: $\quad$ There is a significant best predictor among transformational leadership and school culture on organizational health of secondary schools in the Northern State of Peninsular Malaysia as perceived by teachers.

HA5: There is a significant influence of school culture on the relationship between transformational leadership and organizational health of secondary schools in the Northern State of Peninsular Malaysia as perceived by teachers.

HA5.1: There is a significant influence of Teacher Collaboration on the relationship between transformational leadership and organizational health of secondary schools in the Northern State of Peninsular Malaysia as perceived by teachers.

HA5.2: There is a significant influence of Unity of Purpose on the relationship between transformational leadership and organizational health of secondary schools in the Northern State of Peninsular Malaysia as perceived by teachers. 
HA5.3: There is a significant influence of Professional Development on the relationship between transformational leadership and organizational health of secondary schools in the Northern State of Peninsular Malaysia as perceived by teachers.

HA5.4: There is a significant influence of Collegial Support on the relationship between transformational leadership and organizational health of secondary schools in the Northern State of Peninsular Malaysia as perceived by teachers.

HA5.5: There is a significant influence of Learning Partnership on the relationship between transformational leadership and organizational health of secondary schools in the Northern State of Peninsular Malaysia as perceived by teachers.

HA5.6: There is a significant influence of Collaborative Leadership on the relationship between transformational leadership and organizational health of secondary schools in the Northern State of Peninsular Malaysia as perceived by teachers.

Figure 1: The Conceptual Framework Based on Transformational Leadership Model

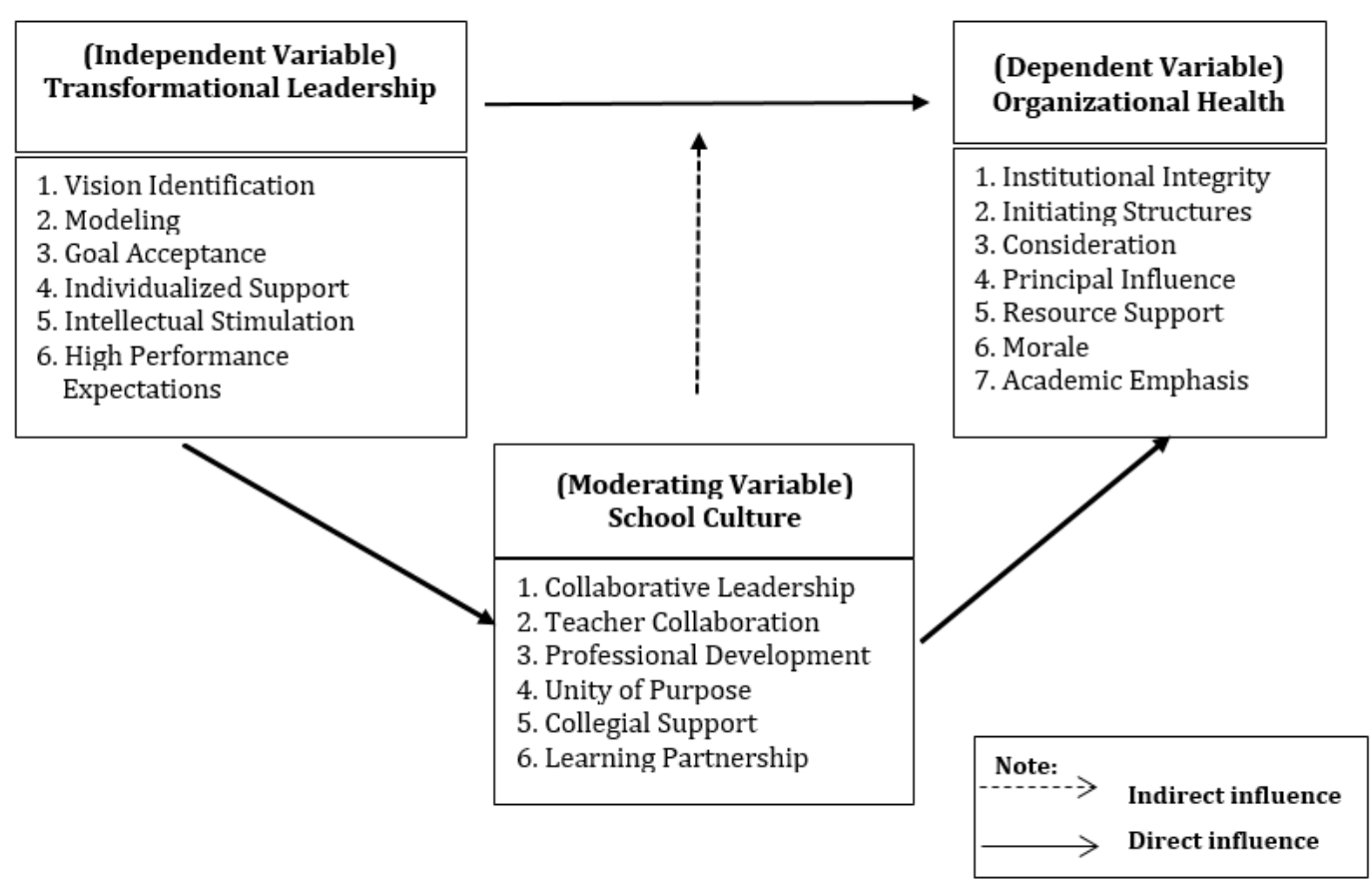

Source: Leithwood \& Jantzi, (1996), School Culture (Gruenert, 1998) and Organizational Health (Hoy et al., 1991)

\section{Significance of the Study}

According to (Nguni et al., 2006), a principal is a hands-on, organized, artistic, inventive, effective and competent leader in their organization. The transformational leadership strategy grounding this study is able to meet the challenges of the modern globalized era (Leithwood \& Jantzi, 2006). Principal's unique culture is to identify a universal learning and teaching methodology for teachers and students in school environment (Gersten et al., 2001). They are the change agents who metamorphose the teaching and learning values in school setting (Sekaran, 2000). According to Littrel et al. (1994), school principals indirectly affect the learning culture and student achievement of the school. Every principal's vision and mission should be to analyze the teaching and learning taking place and seek to achieve continuous improvement in education development (Leithwood et al., 2004).

This study aims to benefit the school principals to identify approaches towards school's improvement and to create an atmosphere of well-being at work among teachers. It can motivate teachers to improve the teaching quality, especially in the classrooms. By doing so they will be able to produce students who will excel physically, emotionally, spiritually and intellectually in line with the national educational philosophy. This study will benefit the following parties:

\subsection{Ministry of Education}

In recent years, the Malaysian education system has come under increased public scrutiny and debate, as parents' expectations rise and employers voice their concern regarding the system's 
ability to adequately prepare young Malaysians for the challenges of the 21st century (Ministry of Education Malaysia). A fundamental objective of any education system is to ensure that its students are being equipped with the knowledge and skills required for success in life. Education in Malaysia is an on-going effort towards further developing the potential of individuals in a holistic and integrated manner so as to produce students who are intellectually, spiritually, emotionally and physically balanced and harmonious. Such an effort is designed to produce young Malaysians who are knowledgeable and competent, who possess high moral standards and who are responsible and capable of achieving a high level of personal well-being as well as being able to contribute to the betterment of the family, the society and the nation at large.

\subsection{Institut Aminuddin Baki (IAB)}

This study will also be significant to IAB to focus on management and leadership development training for school principals. The main institution in the country responsible for the training of school principals is IAB or in English, the National Institute of Educational Management and Leadership (NIEML) (Selamat, Nordin \& Adnan, 2013). IAB can incorporate the needed training and development initiatives in engaging the right candidate as school principals and develop holistic individuals in line with the National Philosophy of Education. Knowledge attained from this research can be used to improve the leadership qualities and skills of the present and future school principals in Malaysia.

\subsection{School Principals}

The data to be collected from this research will enable school principals to examine more closely the impact of their leadership style on the organizational health of their school. Based on the results of the questionnaire and data analysis, principals will be able to utilize the results to change and cultivate a healthier school culture. The research presented in this study could enable school principals to better understand the school leadership practices that positively impact student achievement. This knowledge could have significant implications for improving the effectiveness of school leadership towards the goal of improving the organizational health of the schools.

\subsection{Complement Existing Knowledge}

It is hoped that this study will complement existing literature regarding the influence of transformational leadership and organizational health of secondary schools in Malaysia. With increased literature and knowledge on school leadership behavior, prospective principals and all those involved in education may find the findings useful for identifying behaviors, beliefs and values that could advance the development of a school. Extensive research is conducted in the west about school leadership, teachers and students but this study is central for better understanding of the contemporary issue on the effects of principal leadership on staff behavior and student achievement in the eastern context.

\section{Limitations of the Study}

This study is done with the following limitations:

1. It is not intended to explain or explore the phenomenon of "WH" questions.

2. The sample respondents are only from the selected national secondary schools who are trained teachers. As such, the findings cannot be generalized to represent the total teacher population in the country.

3. The teachers chosen for this study should be a trained teacher and have worked in the same school for at least 2 years. This will ensure the selected teachers have well rounded experience as an educator and a thorough understanding of the school's environment presently. Studies conducted by Martin et al. (2006) found that experienced teachers managed their classrooms more effectively than less experienced teachers. They took more control than did novice teachers in establishing classroom routines and monitoring group work. However, the definition of what constitutes teacher experience varies greatly across the literature. Novice teachers are relatively easily defined as those with little or no classroom experience and have less than 2 years of teaching experience (Hallinger, 2003).

4. This study is to investigate the interaction between the three variables, namely, the wellbeing in the workplace (organizational health), transformational leadership of school principals and school culture. This is because these three dimensions are important 
element in the improvement of the school organization. The variables used in this study are limited to transformational leadership, school culture and organizational health where there are other variables which are not dealt in this study.

\section{Research Methodology}

\subsection{Research Population}

In our country there are 2329 national secondary schools. The population of this study comprises of national secondary schools from three states which are Pulau Pinang, Kedah Darul Aman and Perlis Indera Kayangan. They are 346 national secondary schools in the three states, whereby 127 of the secondary schools are from Pulau Pinang; 189 secondary schools from the state of Kedah Darul Aman and 30 secondary schools are from Perlis Indera Kayangan (Leithwood et al., 2002). The schools that are not included in this study are fully residential schools, high-performing schools, technical secondary schools and Islamic religious schools. Hence, the number of schools that serve the population of this study is 346 national secondary schools. The schools are selected based on the rational that they have the same administration system and also the students have achieved similar academic performance hence, the study results can draw general conclusion of the population with the same criteria.

\subsection{Respondents Sampling}

This study involved all schools in the state of Pulau Pinang, Kedah Darul Aman and Perlis Indera Kayangan and a total teacher population of 22, 486 individuals. Due to this relatively large population of teachers, the study will use the samples based on the calculation in Table 3.2, which is 2250 teachers. However, to ensure a rate of return of 60 percent (Hersey \& Blanchard, 1996) the researcher will employ approximately 2400 teachers from 346 national secondary schools as respondents for this study (200 schools' x 12 teachers from each school).

\subsection{Research Instrument}

According to (Locke, 1969), descriptive study is undertaken when the characteristics or the phenomena to be tapped in a situation are known to exist and one wants to be able to describe them better by offering a profile of factors. It is suggested by (Harris \& Chapman, 2002) that surveys with diverse type of questioning are a more convenient way of gathering information. Hence, this study chose this type of survey method as opposed to in-depth interviews or focus groups. Self-administered surveys are more convenient and less expensive to administer, eliminates interviewer bias, gives respondents privacy and results can be analyzed more quickly. The self-administered questionnaire consists of four sections; Section A contains Teacher Demographic Information, Section B contains Principal Leadership Questionnaire (PLQ), Section C contains the School Culture Survey Questionnaire (SCS) and finally Section D consists of the Organizational Health Index for Secondary School Questionnaire (OHI-S).

\subsection{Data Analysis Procedures}

This study only uses quantitative data analysis. The quantitative method is conventionally based on the positivist approach to explore scientific inquiry of the phenomena. This also underlies that deductive model which shows hypothesized relationships. The proposed relationships are obvious (Littrel et al., 1994) and seek to quantify an observable consequence through running a statistical experiment thereby getting results, whether the hypothesized relationships hold or not (Littrel et al., 1994). The Statistical Package for Social Sciences (SPSS) version 20.0 will be used to analyze the data collected. There are three techniques of analysis in this study, namely descriptive statistics, inferential statistics and moderating variable function analysis. 


\section{Conclusions}

At this point, no study has been conducted to test the school culture as a moderator to the relationship between transformational leadership and organizational health. In the present study, an attempt is made to investigate the influence of transformational leadership on organizational health of secondary schools in the Northern States of Peninsular Malaysia. In this context, a conceptual model is proposed to study the determinants of transformational leadership, school culture and organizational health of secondary school teachers. This study is particularly timely given Malaysia's Education Blueprint 2013-2035 to create high-performing schools with effective leaders. The blueprint in Malaysia is taking initial steps to map out the future of education in the country, considering not only who will implement these changes, but also how their outlined goals will be accomplished.

\section{Appendix A. Supplementary material}

Supplementary data associated with this article can be found, in the online version, at https://dx.doi.org/10.14254/jems.2018.3-1.2

\section{Funding}

The authors received no direct funding for this research.

\section{Citation information}

Arokiasamy, A. R. (2018). Linking transformational leadership with organizational health of secondary school teachers: A conceptual model and research proposition. Economics, Management and Sustainability, 3(1), 21-33. doi:10.14254/jems.2018.3-1.2.

\section{References}

Arokiasamy, A., \& Lok, S. Y. P. (2014). Causal Relationship between Incentive and Job Satisfaction: Evidence of the Malaysian Academic Staff in Higher Education Institutions. Asian Research Journal of Business Management, 2, 16-27.

Arokiasamy, A, Abdullah, A.G.K \& Ismail, A. (2015). Correlation between Cultural Perceptions, Leadership Style and ICT Usage by School Principals in Malaysia. ELSEVIER-Procedia Social and Behavioral Sciences, 176, 319-332.

Bass, B M \& Avolio, B J, (2003). Improving Organizational Effectiveness through Transformational Leadership, Thousand Oaks, Sage Begley, P \& Johansson, O. The Ethical Dimensions of School Leadership, Dordrecht, Kluwer Academic Publishers.

Bass, B. M., \& Riggio, R. E. (2006). Transformational leadership (2nd ed.). Mahwah, NJ: Lawrence Erlbaum Associates.

Bogler, R., (2001). The influence of leadership style on teacher job satisfaction. Educational Administration Quarterly, 37(5), 662-683.

Cemaloglu, N., Sezgin, F., \& Killing, A.C. (2012). Examining the Relationships between School Principals' Transformational and Transactional Leadership Styles and teachers Organizational Commitment. The Online Journal of New Horizons in Education, 2(2), 53-63.

Creswell, J. W. (2005). Educational research. Planing, conducting and evaluating qualitative and quantitative approaches (3rd ed.). Thousand Oaks, CA: Sage Publications, Inc.

Geijsel, F., Sleegers, P., Leithwood, K. \& Jantzi, D. (2003). Transformational leadership effects on teachers' commitment and effort toward school reform. Journal of Educational Administration, 41(3), 228-256.

Gersten, R., Keating, T., Yovanoff, P., \& Harniss, M. (2001). Working in special education: Factors that enhance special educators' intent to stay. The Council for Exceptional Children, 67(4), 549-567.

Griffith, J. (2004). Relation of principal transformational leadership to school staff job satisfaction, staff turnover, and school performance. Journal of Educational Administration, 42(3), 333356. 
Gruenert, S. (1998). School Culture Survey. Unpublished doctoral dissertation, University of Missouri, Columbia.

Hallinger, P. (2003). Leading educational change: Reflections on the practices of instructional and transformational leadership. Cambridge Journal of Education, 33(3), 329-351. doi: http://dx.doi.org/10.1080/0305764032000122005.

Hallinger, P. (2007). Leadership for Learning: Reflections on the practices of instructional and transformational leadership. Paper presented, Seminar at East Asia University.

Harris, A., \& Chapman, C. (2002). Effective leadership in school facing challenging circumstances. Nottingham: National College for School Leadership.

Harris, A., Day, C., Hopkins, D., Hadfield, M., Hargreaves, A., \& Chapman, C. (2013). Effective leadership for school improvement. London: Routledge.

Heller, H. W., Clay, R., \& Perkins, C. (1993). The relationship between teacher job satisfaction and principal leadership style. Journal of School Leadership, 3, 74-86.

Hersey, P., \& Blanchard, K. H. (1996). The management of organizational behavior (7 ed.). Englewood Cliffs, NJ: Prentice-Hall.

Hoy, W. K., \& Miskel, C. G. (2013). Educational administration. Theory, research, and practice (9th ed.). New York, NY: McGraw Hill.

Leithwood, K., \& Jantzi, D. (2006). A review of transformational school leadership research: 1996 2005. Leadership and Policy in Schools.

Leithwood, K., Jantzi, D., \& Mascall, B. (2002). Large-scale reform: What works. Journal of Educational Change, 3(1), 7-33.

Leithwood, K., Jantzi, D., \& Steinbach, R. (1999). Changing leadership for changing times. Buckingham, UK: Open University Press.

Leithwood, K., Jantzi, D., Earl, L., Fullan, M., Levin, B. (2004). Leadership for large-scale reform. School Leadership and Management, 24(1), 57-80.

Littrell, P.C., Billingsley, B. \& Cross, L. (1994). The effects of principal support on special a general educators' stress, job satisfaction, school commitment, health, and intent to stay in teaching. Remedial and Special Education, 15, 297-310.

Locke, E. (1969). What is job satisfaction? Organizational Behavior and Human Performance, 4, 309336.

Ministry of Education Malaysia. (2014). Pelan Pembanguan Pendidikan Malaysia 2013-2025. Putrajaya: KPM.

McLeskey, J., Tyler, N.C., \& Flippin, S.S. (2004). The supply and demand of for special education teachers: A review of research regarding the chronic shortage of special education teachers. The Journal of Special Education, 38(1), 5-21.

Muijs, D, Harris, A, Chapman, C, Stoll, L \& Russ, J. (2004). Improving schools in socio-economically disadvantaged areas: A review of research evidence. School Effectiveness and School Improvement, 15(2).

Nguni, S., Sleegers, P., \& Denessen, E. (2006). Transformational and transactional leadership effects on teachers' job satisfaction, organizational commitment, and organizational citizenship behavior in primary schools: The Tanzanian case. School Effectiveness and School Improvement, 17(2), 145-177.

Noor Rezan Bapoo Hashim (2009). Sekolah Kluster Lonjak Institusi Pendidikan (Cluster School Accelerate the Educational Institutions) in Majalah Pendidik (Educators Digest), 18-21.

Rahman Sukor bin Abdul Samad (2010). Education management in the context of quality improvement: managing change for improving learning community. Jurnal Pendidikan, 30(2), 93-108.

Reitzug, U. C., \& Patterson, J. (1998). " I'm Not Going to Lose You!" Empowerment Through Caring in an Urban Principal's Practice With Students. Urban education, 33(2), 150-181. 
Selamat, N., Nordin, N., \& Adnan, A. A. (2013). Rekindle teacher's organizational commitment: the effect of transformational leadership behavior. Procedia-Social and Behavioral Sciences, 90, 566-574. http://dx.doi.org/10.1016/j.sbspro.2013.07.127

Seltzer, J., \& Bass, B. M. (1990). Transformational leadership: Beyond initiation and consideration. Journal of management, 16(4), 693-703.

Silins, H., \& Mulford, B. (2002). Leadership and school results. In Second international handbook of educational leadership and administration (pp. 561-612). Springer, Dordrecht.

Spector, P. (1997). Job Satisfaction: Application, Assessment, Causes and Consequences. California: Sage.

Spunt, T. M. (1999). Guide to customer surveys: Sample questionnaires and detailed guidelines for creating effective surveys. New York, NY: Customer Service Group.

Uma, Sekaran, (2000). Research Methods for Business: A Skill-building Approach. Third Ed. New York: John Wiley \& Sons, Inc., p. 288.

Zaidatol Akmaliah (1990). Pentadbiran Pendidikan. Shah Alam: Penerbitan Fajar Bakti Sdn. Bhd.

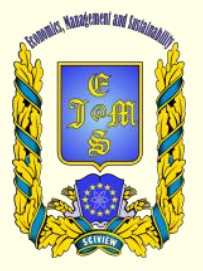

C) 2016-2018, Economics, Management and Sustainability. All rights reserved.

This open access article is distributed under a Creative Commons Attribution (CC-BY) 4.0 license.

You are free to:

Share - copy and redistribute the material in any medium or format Adapt - remix, transform, and build upon the material for any purpose, even commercially.

The licensor cannot revoke these freedoms as long as you follow the license terms.

Under the following terms:

Attribution - You must give appropriate credit, provide a link to the license, and indicate if changes were made.

You may do so in any reasonable manner, but not in any way that suggests the licensor endorses you or your use.

No additional restrictions

You may not apply legal terms or technological measures that legally restrict others from doing anything the license permits.

Economics, Management and Sustainability (ISSN: 2520-6303) is published by Scientific Publishing House "CSR", Poland, EU and Scientific Publishing House "SciView", Poland

Publishing with JEMS ensures:

- Immediate, universal access to your article on publication

- High visibility and discoverability via the JEMS website

- Rapid publication

- Guaranteed legacy preservation of your article

- Discounts and waivers for authors in developing regions

Submit your manuscript to a JEMS at http://jems.sciview.net or submit.jems@sciview.net 